\title{
INFLUENCE OF CALCIUM HYDROXIDE ON DYES FOR DENTIN LABELING, ANALYZED BY MEANS OF A NEW METHODOLOGY
}

\author{
INFLUÊNCIA DO HIDRÓXIDO DE CÁLCIO SOBRE CORANTES NA MARCAÇÃO \\ DENTINÁRIA, ANALISADA POR MEIO DE UMA NOVA METODOLOGIA
}

Ivaldo Gomes de MORAES ${ }^{1}$, Fernanda Gomes de MORAES ${ }^{2}$, Graziela Garrido MORI ${ }^{3}$, Silvana Beltrami GONÇALVES ${ }^{2}$

\author{
1- Associate Professor of Endodontics - University of São Paulo, Bauru Dental School. \\ 2- PhD Student, Endodontics - Bauru Dental School - University of São Paulo. \\ 3- PhD in Endodontics - Bauru Dental School - University of São Paulo. \\ Corresponding address: Dr. Ivaldo Gomes de Moraes. Al. Octávio Pinheiro Brisolla, 9-75, Vila Universitária, Bauru-SP, Brazil \\ Cep.: 17012 901. Email: grazielagm@uol.com.br
}

Received: March 23, 2004 - Modification: June 23, 2004 - Accepted: July 08, 2005

\begin{abstract}
$T_{1}$

he objective of this study was to evaluate the influence of calcium hydroxide in intracanal dressing on the ability of the dyes rhodamine B and methylene blue to label the dentine. Forty extracted human mandibular premolars had their canals instrumented and were divided into four groups: in two groups, the canals were filled with a calcium hydroxide paste and the others remained in distilled water. After 15 days, in two groups (with and without dressing), the canals were obturated with sealer containing methylene blue, whereas the others contained rhodamine B. For analysis, the roots were transversally sectioned in their cervical, medium and apical thirds, and the labeling was analyzed. The Mann-Whitney test showed statistically significant difference between the dressing/methylene blue group and the others. Based on these results, it was concluded that calcium hydroxide in intracanal dressing negatively interferes with the labeling ability of methylene blue.

Uniterms: Methylene blue; Rhodamine B; Dental leakage; Root canal filling materials.
\end{abstract}

\section{RESUMO}

$O$

bjetivou-se avaliar a influência do curativo intracanal de hidróxido de cálcio sobre a capacidade dos corantes azul de metileno e rhodamine B de marcar a dentina, quando incorporados à massa obturadora, no momento da espatulação. Quarenta pré-molares inferiores humanos extraídos tiveram seus canais instrumentados sendo, então, divididos em quatro grupos. Em dois grupos, os canais foram preenchidos com pasta de hidróxido de cálcio e propilenoglicol por 15 dias. Os outros, permaneceram em água destilada. Após a remoção do curativo, todos os canais foram obturados com condensação lateral e cimento de óxido de zinco e eugenol acrescidos de azul de metileno ou rhodamine B. Assim, em dois grupos (com e sem curativo), os canais foram obturados com cimento contendo azul de metileno e os outros, rhodamine B. Decorridos 15 dias, as raízes foram seccionadas transversalmente nos terços cervical, médio e apical, procedendo-se à análise da marcação, com atribuição de escores às características da mesma. O teste de Mann-Whitney acusou marcação estatisticamente menor $(\mathrm{p}<0,05)$ no grupo curativo/azul de metileno. Baseado nos resultados, concluiu-se que o curativo intracanal de hidróxido de cálcio interfere negativamente na capacidade marcadora do azul de metileno, diminuindo-a consideravelmente.

Unitermos: Azul de metileno; Rhodamina B; Infiltração dentária; Materiais obturadores do canal radicular.

\section{INTRODUCTION}

Complete filling of the root canal system is a very important aspect in order to achieve success in endodontic treatment. The quality of apical sealing depends on several factors, such as biomechanical preparation, type of root canal filling material, and obturation technique ${ }^{11}$. There has been the hypotheses that intracanal dressing with calcium hydroxide paste could improve the apical sealing of root canal filling. According to Holland and Murata $^{6}$ (1993), the use of calcium 
hydroxide as intracanal dressing delays marginal leakage in root canal obturations, probably by accelerating the setting time, and causing obturating sealer expansion. In 1995, Holland, Murata and Saliba ${ }^{7}$, confirmed the decrease in marginal leakage in root canal filling due to the use of calcium hydroxide dressing, because, according to the researchers, the calcium hydroxide incorporates to the root canal filling material, forming calcium carbonate at the obturation-root canal wall interface.

A variable number of methods have been used to determine leakage following root canal filling, including the use of labeling dyes $^{1,2,3,5,11}$, radioisotopes ${ }^{2}$, the presence of microorganisms ${ }^{2,4}$, air-propelling devices ${ }^{13}$ and adapted models for fluid transport ${ }^{2,8,13}$. From these methods, dyes are mostly used, mainly methylene blue solution, especially due to its low molecular weight, which enhances its penetration and diffusion into the dentinal tubules and complementary canals $^{1,5,11}$.

Studying texts about the properties of methylene blue, it was observed that it might suffer chemical reactions of reduction when in contact with reducing substances. It may even start to discolor and label with lower intensity ${ }^{9,13}$. Another very important property is the incompatibility between methylene blue and alkaline substances such as calcium hydroxide ${ }^{8,9}$

MORAES, et al. ${ }^{10}$, verified that obturations performed by the lateral condensation technique, having calcium hydroxide paste as the sealer agent, provided excellent sealing, raising doubts about the reality of sealing or the neutralization of methylene blue labeling action by calcium hydroxide.

Taking into account the aforesaid aspects, this work aimed at verifying the dye leakage in the dentinal mass and analyzing the action of calcium hydroxide dressing on methylene blue and rhodamine $\mathrm{B}$, when they are incorporated to the root canal filling material at the moment of preparation, as well as the viability of this new methodology.

\section{MATERIALAND METHODS}

Forty human extracted single-rooted mandibular premolars had their crowns sectioned at the cementoenamel junction with the aid of steel discs. Following the odontometry of all root canals, they were instrumented by the stepback technique with programmed stepback using as instrument the file K\# 45 , going gradually to file K\# 60 . During preparation, the root canals were irrigated with $1 \%$ sodium hypochlorite and then EDTA (Biodinâmica - Ibiporã - Brasil) was applied for 3 minutes, followed by irrigation with distilled water. The roots then rendered impermeable by application of two coats of varnish, except for the last apical millimeter of the root.

The roots were divided into four groups of 10 elements each. In two groups, the canals were filled with calcium hydroxide paste and propylene glycol (at the ratio of 0.56/ $0.4 \mathrm{ml}$, respectively) with Lentulo spiral. The cervical openings were sealed with Cavit (Dentisply), remaining in medium with $100 \%$ humidity at $37+$ or $-1^{\circ} \mathrm{C}$ for 15 days. The other roots, whose canals had no dressing, remained in distilled water for the same period.

After 15 days, the canals were obturated by the lateral condensation technique, using gutta-percha points and zinc oxide and eugenol sealer, at the ratio of $0.9 \mathrm{~g}$ of zinc oxide and $0.4 \mathrm{ml}$ of eugenol, to which powdered dye was added. The dyes used were methylene blue in quantity equivalent to $2 \%$ or rhodamine B at $0.2 \%$ in relation to the quantity of eugenol. Thus, each $1.0 \mathrm{ml}$ of eugenol was added $0.2 \mathrm{~g}$ of methylene blue or $0.02 \mathrm{~g}$ of rhodamine B in powder at the moment of preparation. Consequently all canals (with or without calcium hydroxide dressing) were obturated with zinc oxide sealer and eugenol containing methylene blue (groups 1 and 2) or rhodamine B (groups 3 and 4).

Fifteen days later, the roots were transversely sectioned at the cervical, medium and apical thirds, to analyze possible dye leakage in the tooth. Analysis was carried out under light microscope with 10x magnification, establishing scores according to the quantity of labeling around the canal, the depth of dye penetration towards the cementum and the intensity of color (Table 1 ).

The data were recorded in tables, which were used for statistical analysis of results by the Mann-Whitney test, at $5 \%$ significance.

\section{RESULTS}

Tables 2 and 3 show the scores attributed to findings in the groups where methylene blue and rhodamine B were used, respectively, as well as the results of statistical calculations made.

Group 1 (methylene blue without dressing)

It was observed that the whole surface around the canal was marked by the dye (score $=4$ ). As to labeling depth toward the cementum, this varied between scores 3 and 4 , showing that methylene blue penetrated considerably into the dentinal tubules. The color intensity was regular with scores varying from 1 to 3 (Table 2 ).

Group 2 (methylene blue with dressing)

Only half the surface around the canal was labeled by the dye. Regarding depth, the methylene blue leakage occurred in only $1 / 4$ of the surface toward the cementum. The color intensity was score 1 , being observed just in the dentinal tubules, visualized by means of microscopy (Table 2).

Group 3 (rhodamine B without dressing)

It was observed that the entire surface around the canal was labeled by the dye (score $=4$ ). As to the labeling depth toward the cementum, this varied from scores 3 and 4 , showing that rhodamine $\mathrm{B}$ penetrated considerably into the dentinal tubules. The color intensity was strong and obtained score 4 (Table 3).

Group 4 (rhodamine B with dressing)

The whole surface around the canal was labeled by the dye (score $=4$ ). As to depth, there was observed rhodamine B leakage in $3 / 4$ of the mass toward the cementum (scores 1 to 4 ). The intensity of coloring was strong, obtaining scores from 2 to 4 (Table 3). 
Statistical Analysis (Tables 2 and 3)

Comparing groups 1 and 2, obturated with sealer containing methylene blue, it was observed that there was statistically significant difference $(p<0.05)$ with reduced labeling for group 2 (with dressing); whereas among the groups with rhodamine $B$, no difference was observed $(\mathrm{p}<0.05)$.

\section{DISCUSSION}

The incompatibility of methylene blue with alkaline substances such as calcium hydroxide and the hypotheses raised by MORAES, et al. ${ }^{10}$ of some chemical interaction of calcium hydroxide and the dentine, making the later not to be marked by the dye and seem impermeable against the dye were the most accepted reasons for the better performance of obturations in canals that had calcium hydroxide dressing. In this case the sealing would be false positive although Holland and Murata ${ }^{6}$ state there is an expansion of sealer in contact with calcium hydroxide, improving sealing process.

Considering the uncertainties regarding the sealing provided by obturations of canals submitted to calcium hydroxide, the possibility of incorporating dyes to obturating sealer at the moment of preparation has been raised. Although the totality of works use dyes diluted in water as markers, this new methodology started from the thought that the liquid (eugenol), separating from the sealer powder during the obturation process may penetrate the tooth mass via dentinal tubules, carrying the dye with it, thus labeling the root dentine.

TABLE 1- Scores used in the research, taking into account factors such as quantity of labeling around the canal, depth of dye leakage toward the sealer and intensity of coloring

\begin{tabular}{|c|c|c|c|}
\hline Scores & $\begin{array}{l}\text { labeling around } \\
\text { the canal }\end{array}$ & $\begin{array}{l}\text { depth of dye leakage toward } \\
\text { the cementum }\end{array}$ & intensity of coloring \\
\hline 0 & & & \\
\hline 1 & $\begin{array}{l}1 / 4 \text { of the surface } \\
\text { around the canal }\end{array}$ & $1 / 4$ in toward the cementum & always in the dentinal tubules \\
\hline 2 & $\begin{array}{l}2 / 4 \text { of the surface a } \\
\text { around the canal }\end{array}$ & $2 / 4$ in toward the cementum & weak \\
\hline 3 & $\begin{array}{l}3 / 4 \text { of the surface } \\
\text { around the canal }\end{array}$ & $3 / 4$ in toward the cementum & regular \\
\hline 4 & $\begin{array}{l}4 / 4 \text { of the surface } \\
\text { around the canal }\end{array}$ & $4 / 4$ in toward the cementum & strong \\
\hline
\end{tabular}

TABLE 2- Values for mean $(X)$, median $(M), 1^{\text {st }}$ quarter $\left(1^{\text {st }} Q\right), 3^{\text {rd }}$ quarter $\left(3^{\text {rd }} Q\right)$ and probability $(p)$ for the scores given in the groups of methyl blue in the conditions with and without dressing

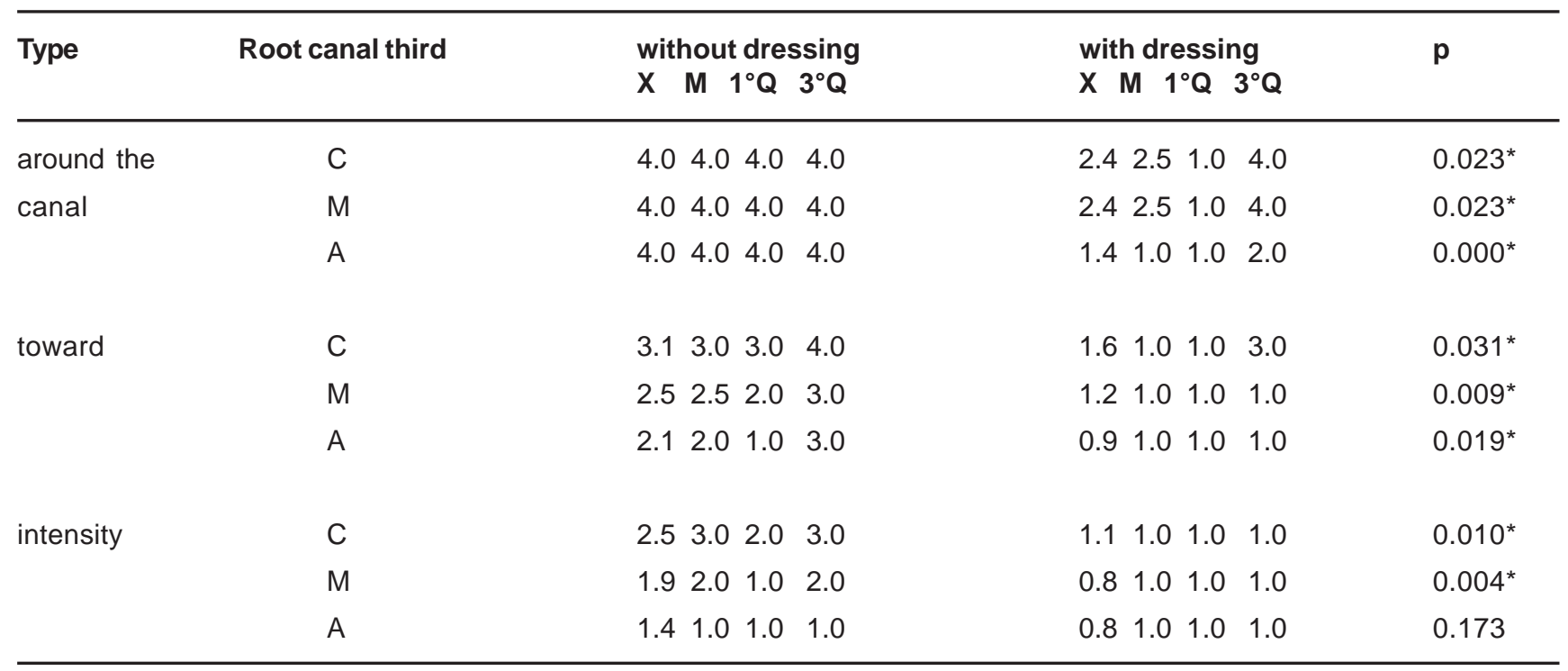

* statistically significant difference $(p<0.05)$

C: cervical third; M: medium third; A: apical third 
This possibility would permit to corroborate the real interference of calcium hydroxide over the labeling ability of methylene blue, since the dentine treated with calcium hydroxide would not be dyed by methyl blue. Actually, the hypothesis was raised because, by the statistical analysis, there were significant differences between group 2 (dressing/ methylene blue) and group 1 (without dressing/ methylene blue) - Table 2.

Although there has been a slight decrease in the labeling strength of rhodamine B on the dentine submitted to calcium hydroxide dressing, it has been insignificant (Table 3). These results are in conformity with data found by Torabinejad, et al. ${ }^{12}$ when submitting root end filling with MTA to methylene blue and rhodamine $\mathrm{B}$.

Thus, research works on marginal leakage where alkaline materials are tested or those that contain calcium hydroxide in their formula and make use of methylene blue as labeling agent must be carefully regarded, because the results may not be real, since leakage may have occurred and may be masked by neutralization of labeling ability of methylene blue. It is advisable, in such cases, to use other markers or other methods.

\section{REFERENCES}

1- Ahlberg KMF, Assananop P, Tay WMA. Comparison of the apical dye penetration patterns show by methylene blue and India ink in root-filled teeth. Int Endod J. 1995;28:30-4.

2- Al-Ghandi W. Testing of sealing abitily of endodontic filling materials. Endod Dent Traumatol. 1994;10:249-55.

3- Bonetti Filho I, Leal JM, Mendes AJD. Avaliação in vitro da capacidade seladora de diferentes técnicas de obturação dos canais radiculares através da infiltração do corante Rhodamine B a 0,2\%. Rev Odontol Clin. 1987;1:17-21.
4- Goldberg F, Bernat MI, Spielberg C, Massone EJ, Piovano SA. Analysis of the effect of thylenediaminetetraacetic acid on the apical seal of root canal filling. J Endod. 1985;11:544-7.

5- Holland R, Alexandre AC, Murata, SS, dos Santos CA, Dezan Junior E. Apical leakage following root canal dressing with calcium hydroxide. J Endod. 1996;22:71-3.

6- Holland R, Murata SS. Efeito do hidróxido de cálcio como curativo de demora no selamento marginal após a obturação de canal. Rev Assoc Paul Cirur Dent. 1993;47:1203-7.

7- Holland R, Murata SS, Saliba O. Efeito a curto e médio prazo dos resíduos de hidróxido de cálcio na qualidade do selamento marginal após a obturação de canal. Rev Paul Odontol. 1995;17:12-6.

8- Kontakiotis EG, Wu MK, Wesselink, PR. Effect of calcium hydroxide dressing on seal permanent root filing. Endod Dent Traumatol. 1997;13:281-4.

9- Methylene blue. In: Budavari S, eds. The merck Index. 11 ed. Rahway: Merck; 1989.

10- Moraes IG, Nunes E, Berbert A, Duarte MAH, Betti LV. Influência do hidróxido de cálcio e do EDTA na marcação da infiltração marginal de azul de metileno em obturação de canais radiculares. Rev FOB. 2000;8:37-44.

11- Porkaew O, Retief DH, Barfield RD, Lacefield WR, Soong SJ. Effects of calcium hydroxide paste as an intracanal medicament on apical seal. J Endod. 1990;16:369-74.

12- Torabinejad M, Watson TF, Pitt Ford TR. Sealing ability of a Mineral Trioxide Aggregate when used as a root end filling material. J Endod. 1993;19: 591-5.

13- Wu MK, Kontakiotis EG, Wesselink PR. Decoloration of $1 \%$ methylene blue solution in contact with dental filling materials. J Dent. 1998;26:585-9.

TABLE 3- Values for mean $(X)$, median $(M), 1^{\text {st }}$ quarter $\left(1^{\text {st }} Q\right), 3^{\text {rd }}$ quarter $\left(3^{\text {rd }} Q\right)$ and probability $(p)$, for the scores given in the groups of rhodamine $B$ in the conditions with and without dressing

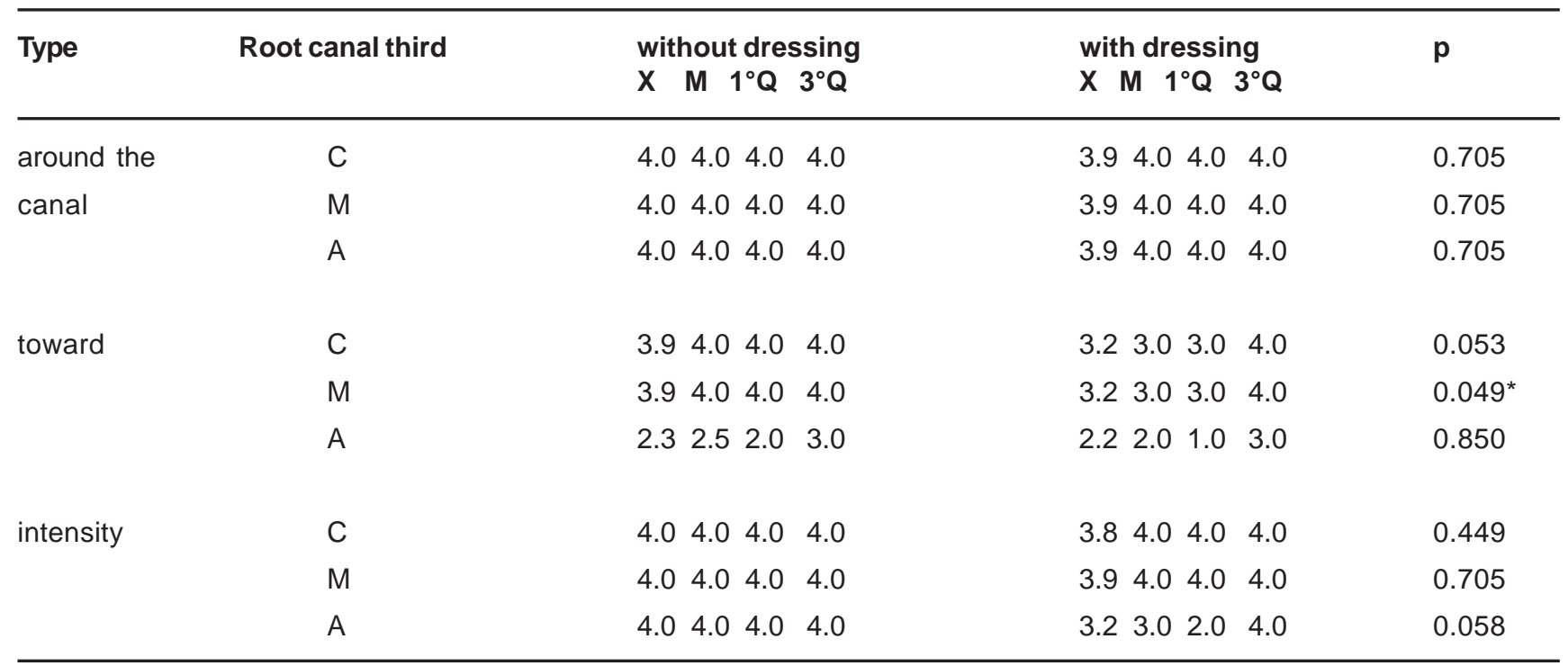

\footnotetext{
* statistically significant difference $(p<0.05)$

C: cervical third; M: medium third; A: apical third
} 